\title{
Land use impact on soil erosion at different scales in the Brazilian semi-arid ${ }^{1}$
}

\author{
Impacto do uso do solo na erosão do solo em diferentes escalas no semiárido brasileiro
}

\author{
Julio Cesar Neves dos Santos ${ }^{2 *}$, Eunice Maia de Andrade ${ }^{3}$, Pedro Henrique Augusto Medeiros ${ }^{4}$, Maria João \\ Simas Guerreiro ${ }^{5}$ and Helba Araújo de Queiroz Paláció
}

\begin{abstract}
Erosion and sediment transport processes are strongly dependent on the spatial scale and land use. The objective of this study is to analyse the effects of slash and burn of vegetation followed by grass cultivation for grazing, on the hydrological and sedimentological behaviour at different spatial scales in a semiarid region in Brazil. Rainfall, runoff and soil loss were measured during three years (total of 116 rainfall-runoff events) at three spatial scales: $1 \mathrm{~m}^{2}$ and $20 \mathrm{~m}^{2}$ plots and 2.8 ha watershed. During the first year (2009) the native dry tropical forest/Caatinga vegetation was maintained, whereas on the following years (2010 and 2011) the original vegetation was cleared using slash and burn techniques to grow pasture (Andropogon gayanus Kunt). Annual runoff coefficient is highest at the $20 \mathrm{~m}^{2}$ plot among the investigated scales. Runoff presented the same trend in all years. Sediment yield was strongly influenced by the land cover. Slash, burn and pasture cultivation strongly impacted sediment yield: the first two events after the land cover change yielded roughly ten times more sediment than similar events in the years with native cover and after grass development. The change was most noticeable at the catchment scale due to erosion along the stream, redefining the drainage network.
\end{abstract}

Key words: Hydrological and sedimentological behaviour. Soil loss. Scale effect.

RESUMO - Erosão e os processos de transporte de sedimentos são fortemente dependentes da escala espacial e uso do solo. O objetivo deste estudo é analisar os efeitos do desmatamento, seguido de queima e cultivo de capim para pastagem, sobre o comportamento hidrológico e sedimentológicos em diferentes escalas espaciais na região semiárida do Brasil. Precipitação, escoamento superficial e perda de solo foram mensurados durante três anos (total de 116 eventos chuva-vazão) em três escalas espaciais: parcelas de erosão de $1 \mathrm{~m}^{2}, 20 \mathrm{~m}^{2}$; e microbacia de 2,8 ha. Durante o primeiro ano de estudo (2009) foi mantida a vegetação de caatinga nativa, enquanto que nos anos seguintes (2010 e 2011) a vegetação original foi alterada usando técnicas de desmatamento, queima e cultivo de capim (Andropogon gayanus Kunt). Os coeficientes de escoamento superficial anual foram mais altos nas parcelas de $20 \mathrm{~m}^{2}$, entre as escalas investigadas. Os coeficientes de escoamento superficial apresentaram a mesma tendência em todos os anos estudados. Já a produção de sedimentos foi fortemente influenciada pela cobertura da terra. Desmatamento, queimada e o cultivo de capim para pastagem impactaram fortemente a produção de sedimentos: os dois primeiros eventos, após a mudança da cobertura do solo, produziram cerca de dez vezes mais sedimentos do que em eventos semelhantes nos anos com cobertura nativa e/ou depois do desenvolvimento do capim. As mudanças foram mais perceptíveis na escala de bacia devido à erosão e redefinição da rede de drenagem.

Palavras-chave: Comportamento hidrológico e sedimentológico. Perdas de solo. Efeito de escala.

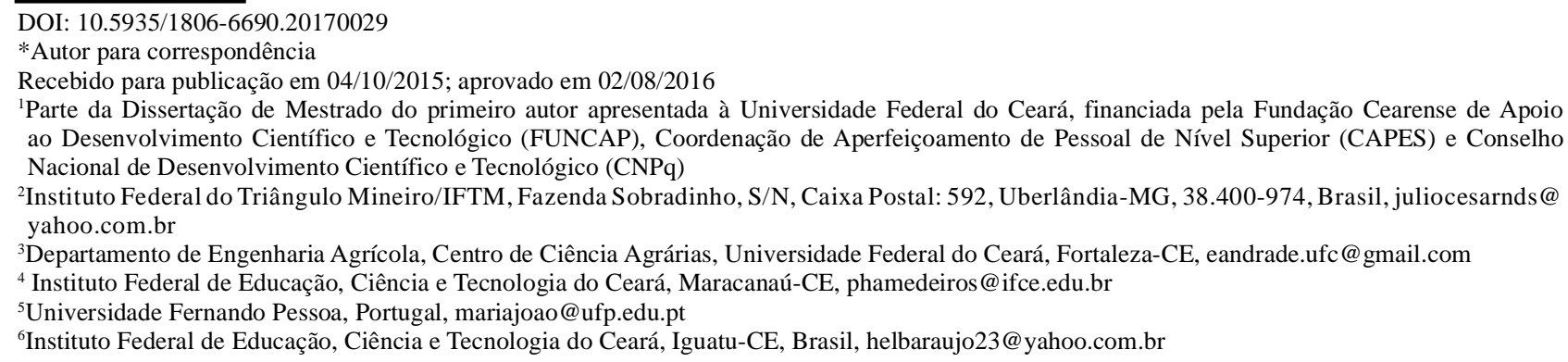




\section{INTRODUCTION}

Soil erosion is a process of detachment and transportation of soil materials by rainfall and runoff, wind, gravity and other natural or anthropogenic agents that disaggregate and remove soil materials at one point on the Earth's surface and deposit it elsewhere (VERHEIJEN et al., 2009). Soil erosion pollutes water and degrades land by reducing fertility, water-storage capacity, and organic matter (CERDAN et al., 2010), which may lead to land abandonment (BAKKER et al., 2005).

Water erosion includes rill and sheet erosion, with the detachment of sediment from the soil surface profile only (MERRITT et al., 2003). For simplification purposes the two processes are often considered together in erosion modelling: sheet erosion, through raindrop action and runoff, removes an uniform thin layer (or sheet) of the fertile upper soil horizon (DLAMINI et al., 2011); and rill erosion that scours and transports sediments through a concentrated flow of water in narrow, erodible channels (YAN et al., 2008).

Changes in land use and land management may increase soil erosion. A decrease in soil surface covered by vegetation affects sheet erosion (DLAMINI et al., 2011; ORCHARD et al., 2013; PODWOJEWSKI et al., 2011). Chaplot et al. (2005) concluded that land use change from forest to crops (9\% to 100\%) may increase rill erosion up to $600 \%$, and Gafur et al. (2003) found that human intervention has influenced sediment yield in Bangladesh. The scientists of the aforementioned studies intentionally altered land use by slash and burn practices, changing hydrological behaviour and sediment yields in the studied plots.

Erosion processes differ at different spatial and temporal scales. De Vente and Poesen (2005), observed that sediment yield per unit drainage area increased with increasing drainage area, because as watersheds get larger, additional erosion processes, like gully, hillslope, and sheet erosion become possible (OAKES et al., 2012). Nonetheless, above a certain drainage area, sediment production is overcome by sediment transport and sediment deposition rather than active erosion (DE VENTE; POESEN 2005; MAYOR et al., 2011), and sediment production then decreases with increasing drainage area. This occurs due to the increased opportunity for runoff to infiltrate through vegetation patches along the slopes and limestone fractures and due to transmission losses through the channel bed.

In watersheds larger than $10 \mathrm{~km}^{2}$, sediment deposition often prevails over sediment detachment, being a transport limited system. Contrarily, in small erosion plots detachment prevails, being a splash predominant system. Sediment yields are, therefore, reduced in larger areas when compared to small erosion plots (BOIXFAYOS et al., 2005, 2007).

Due to the importance of scale effects on runoff and erosion rates, the definition of scale relationships, as well as the knowledge of the dominant processes and factors governing surface fluxes of water and sediment at each scale, is fundamental for both hydrological modeling and resources management in semiarid areas (MAYOR et al., 2011).

The objective of this study is to analyse the land use change effects on the hydrological processes in a semiarid region, and to investigate the relationships between these processes at different spatial scales.

\section{MATERIAL AND METHODS}

The study area is the Iguatu Experimental Watershed (IEW), located in the semi-arid region of Ceará, in the Upper Jaguaribe Basin, Brazil. The region is within the 'Drought Polygon', between coordinates 6 $6^{\circ} 3{ }^{\prime} 36^{\prime}$ 'S and $6^{\circ} 23^{\prime} 57^{\prime \prime} \mathrm{S}$ and $39^{\circ} 15^{\prime} 15^{\prime \prime} \mathrm{W}$ and $39^{\circ} 15^{\prime} 30^{\prime \prime}$ W with an average elevation of $217.8 \mathrm{~m}$. Monitoring of hydrological and sedimentological processes was carried out at three spatial scales: a 2.8 ha catchment, a $20 \mathrm{~m}^{2}$ erosion plot, and a $1 \mathrm{~m}^{2}$ microplot, all under natural rainfall conditions.

Climate in the region is a BSw'h' type (hot semiarid), according to the Köppen climate classification, with average temperatures always above $18{ }^{\circ} \mathrm{C}$ in the coldest month. The Aridity Index proposed by Thornthwaite is 0.44 , classifying the area as semiarid. The average potential evapotranspiration is $1,988 \mathrm{~mm} . \mathrm{yr}^{-1}$ whereas the average rainfall recorded in the city of Iguatu is $867 \pm 304 \mathrm{~mm}$ (1932 to 2011 ) with $85 \%$ of annual rainfall concentrated from January to May, of which about 30\% recorded in March.

The terrain is slightly hilly with an average watershed slope of $5.57 \%$ (Table 1). Soils are relatively deep (3 meter) with silt $(38.7 \%)$ and clay $(32.2 \%)$ in the surface and subsurface layers. Clay type is a $2: 1$ montmorillonite, which shows deep surface cracks in the dry season and intensifies flooding during the rainy season, compromising crop development and access to the area.

In the first year of study, the native dry tropical forest-caatinga vegetation of the catchment was maintained (Figure 1a). At the end of the dry season (December) of the first year of study, 2009, slash and burn was performed on the catchment, consisting of vegetation clearing followed by burning (Figure 1b) and grass cultivation (Andropogon gayanus Kunt) for grazing (Figure 1c and d). 
Table 1 - Morphometric characteristics of the experimental catchment, Ceará, Brazil

\begin{tabular}{lrc}
\hline \multicolumn{1}{c}{ Morphometric characteristics } & Value & Unit \\
\hline Area & 2.80 & ha \\
Perimeter & 696.75 & $\mathrm{~m}$ \\
Thalweg length & 187.90 & $\mathrm{~m}$ \\
Channel length & 238.20 & $\mathrm{~m}$ \\
Catchment length & 253.90 & $\mathrm{~m}$ \\
Catchment average slope & 5.57 & $\%$ \\
Compactness coefficient & 1.17 & - \\
Channel sinuosity & 1.27 & - \\
\hline
\end{tabular}

Figure 1 - Experimental catchment with (a) native dry tropical forest-caatinga in 2009 (b) after slash and burn management practice with growing grass in the first (2010) and second (2011) year post slash and burn (c and d, respectively)
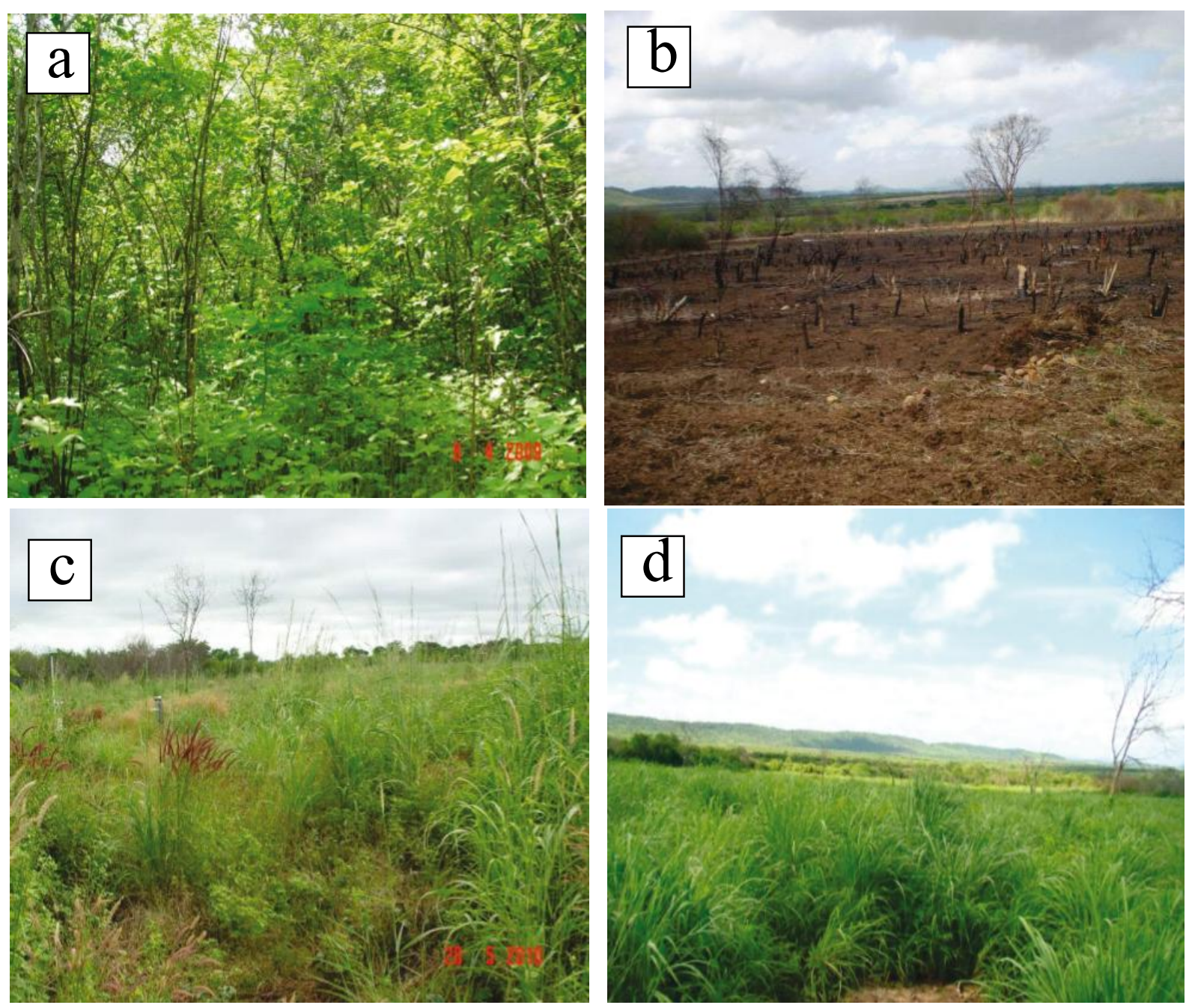

Rainfall, runoff and sediment data were collected during the rainy seasons of the years 2009 to 2011, with a total of 116 natural rainfall events recorded.

The catchment is equipped with an automatic weather station. A tipping bucket and a Ville de Paris rain gauges recorded precipitation data, with 5 min intervals. 
Surface flow was measured using a Parshall flume with a pressure probe, which recorded water level every five minutes. At the catchment scale, suspended sediment and bedload were measured with a sediment sampling tower, and an open ditch with a total capacity of $185 \mathrm{~L}$ installed upstream from the Parshall flume.

The sediment sampling tower contained $100 \mathrm{~mL}$ bottles that were filled during the rising limb of the floods. Collectors were arranged equidistantly, $7.5 \mathrm{~cm}$ apart from each other, the first being $15 \mathrm{~cm}$ above the ground. Water samples were collected from the tower after the runoff generating events and analysed for total suspended solids.

The open ditch retained bedload. After each runoff generating event the water and sediment collected at the ditch were homogenised and a sample collected for total solids quantification.

At the $20 \mathrm{~m}^{2}$ scale plot, runoff and erosion were measured by an experimental plot with dimensions of $2 \times 10 \mathrm{~m}$, the longer length following the direction of the terrain slope. The plot was enclosed by a $30 \mathrm{~cm}$ high steel sheet, buried $15 \mathrm{~cm}$ into the soil. The lower side of the plot was connected to a flow collection system consisting of three tanks of 30, 100 and $200 \mathrm{~L}$ placed sequentially. The first tank contained seven top outlets, so that once filled, one-seventh of the excess volume was transferred to the second tank. The surplus of the second tank was led into the third tank and, thus total runoff volume was evaluated from measurements taken at the three tanks.

Soil loss was estimated from samples collected at the first tank after complete mixing of its content. Samples collection was carried out after all flow-generating rainfall events.

At the micro scale level, a circular erosion plot of $1 \mathrm{~m}^{2}$ was installed in 2011. The round shape helped reduce sediment accumulation at the lower edges of the plot. A $30 \mathrm{~cm}$ high steel sheet buried to a depth of $15 \mathrm{~cm}$ enclosed the area and was connected to an $18 \mathrm{~L}$ capacity bucket, itself connected to a $200 \mathrm{~L}$ tank. Once the bucket was filled, it overflowed into the tank and runoff and total sediment were measured.

The erosivity index $\left(\mathrm{EI}_{30}\right)$ was quantified based on rainfall kinetic energy (KE) by the equation proposed by Wischmeier and Smith and modified by Foster et al. (1981) for SI units. Maximum rainfall intensity over a thirtyminute period, $\mathrm{I}_{30}$ and rainfall intensity were obtained for each rainfall event.

$K E=0.119+0.0873 \log I$

$E I_{30}=K E \times I_{30} \times R$

Where:
$K E$ - rainfall kinetic energy, $\mathrm{MJ} \mathrm{ha}^{-1} \mathrm{~mm}^{-1}$;

$I$ - rainfall intensity, $\mathrm{mm} \mathrm{h}^{-1}$;

$E I_{30}$ - erosivity index, $\mathrm{MJ} \mathrm{mm} \mathrm{ha}^{-1} \mathrm{~h}^{-1}$;

$I_{30}$ - maximum rainfall intensity over a thirty-minute period, $\mathrm{mm} \mathrm{h}^{-1}$;

$R$ - event rainfall, $\mathrm{mm}$.

\section{RESULTS AND DISCUSSION}

\section{Rainfall characteristics}

Rainfall is what mostly affects runoff and soil erosion in tropical regions (THOMAZ, 2009). Therefore its characterization is essential for an adequate evaluation of runoff and soil loss. Average event rainfall in the three year period was $25.1 \mathrm{~mm}$ (Table 2) from a total annual precipitation of 896, 711, and 1,299 $\mathrm{mm}$ in 2009, 2010, 2011, respectively (Table 3).

Rainfall events greater than $51 \mathrm{~mm}\left(85^{\text {th }}\right.$ percentile) represent $14.7 \%$ (17 events) of total events and concentrate $36 \%$ of the precipitation recorded in the studied period. Such behaviour reflects the rainfall pattern in the semi-arid region of Brazil, where a few events of high magnitude are responsible for most of the runoff and soil loss (MEDEIROS; ARAÚJO, 2014). During the studied period the 17 rainfall events with erosivity indexes greater than $482 \mathrm{MJ} \mathrm{mm} \mathrm{ha}^{-1} \mathrm{~h}^{-1}$ (events above the $85^{\text {th }}$ percentile) summed $55.6 \%$ of all erosivity, and were runoff generating events. Extreme rainfall events with high erosivity are responsible for a major percentage of soil erosion. Similar results were reported by Boix-Fayos et al. (2005) in Mediterranean areas.

The high erosivity index events present large amounts of energy available to detach soil particles. This fact is particularly relevant in the region in January and February, on the onset of the rainy season, when the soil is unprotected due to the deciduous nature of the dry tropical forest plant species. Since the soil in this semiarid region may be dry for a period of seven months (or more), antecedent moisture content in the first events is very low and precipitation events may not result in runoff. Nonetheless, sediment transport depends on runoff occurrence and transport capacity (YAN et al., 2008).

The protective effect of vegetation on energy dissipation may be observed in the first events of the months of January and February 2009, 2010, and 2011, when accumulated erosivities were 2,019;2,035 and 4,552 MJ mm ha ${ }^{-1} \mathrm{~h}^{-1}$, respectively (Table 3 ). Sediment yield in those months was $86,2,307$ e $523 \mathrm{~kg} \mathrm{ha}^{-1}$ in 2009 , 2010 and 2011, respectively (catchment scale). Since in 
Table 2 - Frequency analysis rainfall, I30max and EI30

\begin{tabular}{lcccc}
\hline \multirow{2}{*}{$N$} & Valid & Rainfall & I30max & EI30 \\
\cline { 2 - 5 } & & 116 & 116 & 116 \\
\cline { 2 - 5 } & Missing & 0 & 0 & 0 \\
\hline Mean & & 25.1 & 27.6 & 204.3 \\
Median & & 18.6 & 21.2 & 84.2 \\
Std. Deviation & & 18.9 & 19.0 & 273.6 \\
Minimum & & 1.3 & 3.0 & 1.2 \\
Maximum & & 90.3 & $1,375.1$ \\
Sum & & $2,906.9$ & 13.2 & $23,696.4$ \\
\hline & 25 & 10.7 & 21.2 & 30.1 \\
Percentiles & 50 & 18.6 & 37.3 & 84.2 \\
& 75 & 33.3 & 55.9 & 245.9 \\
\end{tabular}

Table 3 - Annual rainfall, EI30 and maximum Imax and EI30 values

\begin{tabular}{cccccc}
\hline Year & Rainfall $(\mathrm{mm})$ & Number of events & Max of I30 max $\left(\mathrm{mm} \mathrm{h}^{-1}\right)$ & Max of EI30 $\left(\mathrm{MJ} \mathrm{mm} \mathrm{ha}^{-1} \mathrm{~h}^{-1}\right)$ & Annual EI30 $\left(\mathrm{MJ} \mathrm{mm} \mathrm{ha}^{-1} \mathrm{~h}^{-1}\right)$ \\
\hline 2009 & 896 & 37 & 77 & 936 & 5718 \\
2010 & 711 & 26 & 59 & 679 & 5338 \\
2011 & 1299 & 53 & 92 & 1375 & 12642 \\
\hline
\end{tabular}

2009 the soil was covered by natural dry tropical forest vegetation, precipitation events did not generate high runoff events with high transport capacity, being the lowest annual sediment yield of the series. In 2010, because soils were unprotected by the slash and burn practice, sediment transport capacity increased and so did sediment yield. In 2011 , although the erosivity index was higher than the previous year, pasture establishment reduced sediment transport capacity (YAN et al., 2008) and resulted in a lower sediment yield.

\section{Runoff}

The highest values of event runoff occurred at the $20 \mathrm{~m}^{2}$ scale. At the micro scale level $\left(1 \mathrm{~m}^{2}\right.$ plot $)$, flow tended to be reduced due to the scale factor, with lower flow energy and quicker response to runoff (ORCHARD et al., 2013; SADEGHI et al., 2013) when compared to the larger plots (20 $\mathrm{m}^{2}$ and catchment scales) (Figure 2), as also verified by Chaplot and Le Bissonais (2000) and Oakes et al. (2012). Catchment length effect on erosion rates has been analysed in Mediterranean watersheds by other authors (DE VENTE; POESEN, 2005; MAYOR et al., 2011).
In 2009 (native dry tropical forest cover), the runoff coefficient for the $20 \mathrm{~m}^{2}$ plot was slightly lower than that of the catchment scale. However, runoff coefficient $(20 \%$ in 2010 and $44 \%$ in 2011) was higher on the $20 \mathrm{~m}^{2}$ plot than the catchment plot after removal of native vegetation (Figure 2) by $45 \%$ and $54 \%$ in the years of 2010 and 2011, respectively. This may be due to the heterogeneity of the native dry tropical forest, with different vegetation densities, enhancing the opportunity for infiltration in the plot.This effect may be due to preferred infiltration paths as the area increases, and other processes at the catchment scale, such as flow circulation in channels, terrain depressions, and channel transmission losses. Similar behaviour has been observed by different researchers in other regions (BOIX-FAYOS et al., 2007; CHAPLOT et al., 2005; CHAPLOT; LE BISSONAIS, 2000; DLAMINI et al., 2011; LE BISSONAIS et al., 1998).

In 2010, despite the slash and burn operation and resulting greater exposure of the soil, there was a reduction in the runoff coefficient at the catchment scale. This was the result from a lower total annual rainfall of $711 \mathrm{~mm}$ (Table 2) and less events, separated by longer dry periods conducting to a reduction in moisture conditions prior to 
Figure 2 - Annual runoff coefficients at different spatial scales, for the dry tropical forest vegetation cover and splash, burn and cultivation of Andropogon gayanus Kunt

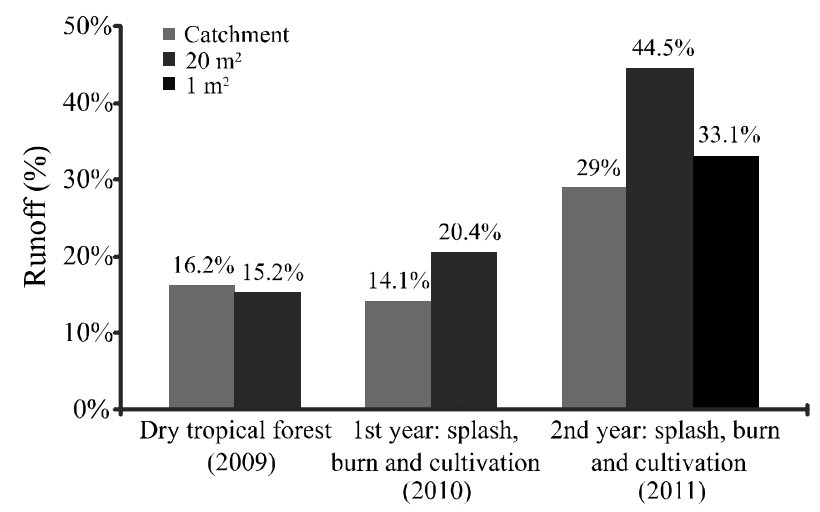

rainfall events. All rainfall events above $40 \mathrm{~mm}$ generated runoff, although runoff volumes depended on antecedent soil moisture, soil cover and rainfall characteristics. Runoff occurrence was uncertain for precipitation events smaller than $40 \mathrm{~mm}$ and a soil moisture above $0.25 \mathrm{~g} \mathrm{~g}^{-1}$. At this scale, the effects of antecedent soil moisture are very significant and represent a major feature governing the infiltration process (GALLART et al., 2002).

After the slash and burn practice and growing of Andropogon gayanus Kunt in 2010, a higher runoff coefficient was observed at the $20 \mathrm{~m}^{2}$ scale compared to the previous year of native dry tropical forest vegetation, despite the lower rainfall amount (Table 2). The effects of the management practice on runoff are evident at the small scale of $20 \mathrm{~m}^{2}$, because of an increased soil exposure and a reduction in the physical barriers (trees, plant litter, etc.) that otherwise reduce flow velocity and enhance infiltration. Similar results were found by Thomaz (2009), where a perceptible increase in runoff coefficient was observed immediately after slash and burn, followed by a continuing decrease in the runoff coefficient in the following years.

Despite increasing soil cover with Andropogon gayanus Kunt in 2011, there was an increase in the runoff coefficient at the catchment and at the $20 \mathrm{~m}^{2}$ scales relative to the previous year with the same treatment. In 2011 a higher rainfall amount was recorded, with rainfall events of higher magnitude and intensity and more frequent events, confirming the importance of rainfall patterns in the process of runoff generation in water scarce environments (GALLART et al., 2002; MEDEIROS et al., 2010; SANTOS et al., 2011).

It is well documented that burning can affect a variety of soil properties, such as nutrient availability, $\mathrm{pH}$, organic matter content, texture, structure. Burning can also have an effect on soil water repellence, thus increasing runoff. Nonetheless, based on the event data, a significant change of the hydrological response at the catchment scale was not observed (Figure 3), implying that profound changes of land cover in the study area not the major runoff factor. Medeiros et al. (2010) verified that vegetation played a secondary role on the runoff generation process in a Brazilian semiarid watershed, in which runoff generation spatial pattern resembled the soil map, indicating that the soil was the main feature controlling the process. Podwojewski et al. (2011) report that soil vegetation cover and overgrazing plays a major role in soil infiltration by water but also suggest that the interrill erosion process is self-increasing. Abandoned cultivated lands and

Figure 3 - Rainfall versus runoff for individual events at the catchment scale
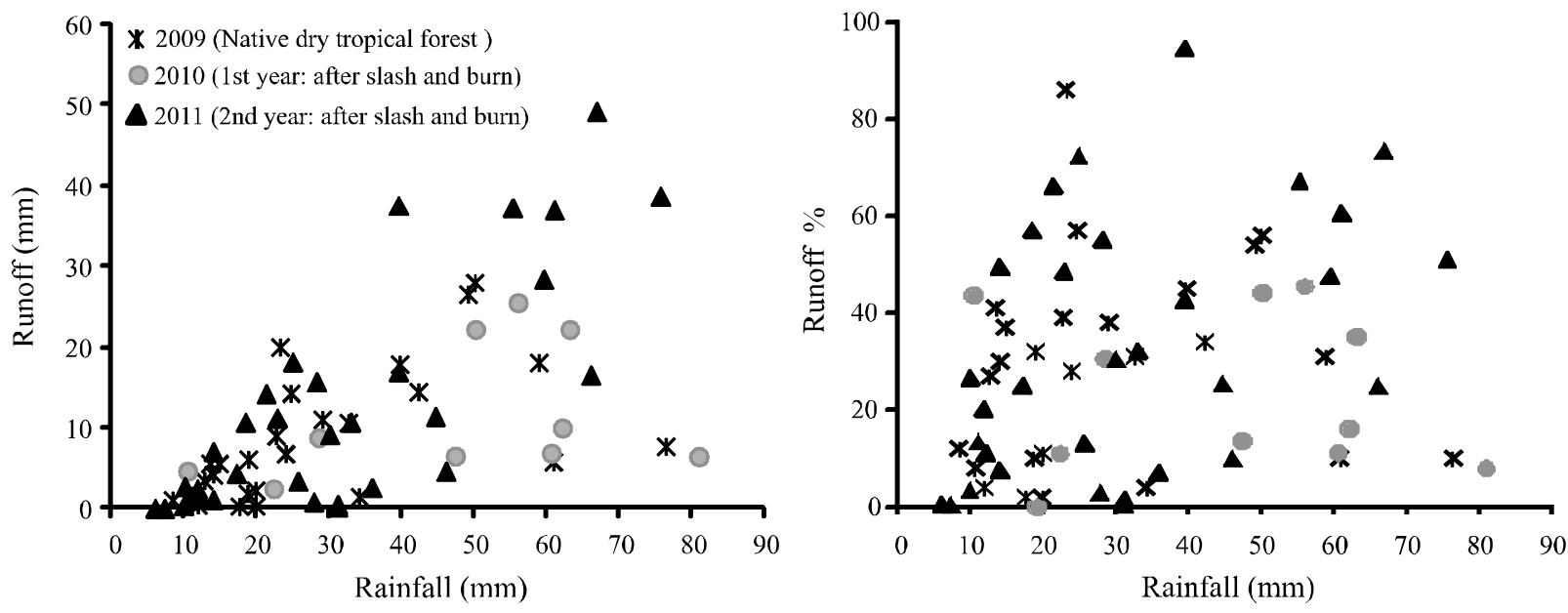
animal preferred pathways are more vulnerable to erosive processes than simply overgrazed rangelands (PODWOJEWSKI et al., 2011).

\section{Soil loss}

The largest specific soil loss occurring at the $20 \mathrm{~m}^{2}$ scale in the years 2009 and 2011 (Figure 4). Nonetheless, soil loss per unit area at the $1 \mathrm{~m}^{2}$ plot was lower than for the $20 \mathrm{~m}^{2}$ plot (Figure 4), as also determined by Oakes et al. (2012) in $10 \mathrm{~m}^{2}$ and $1 \mathrm{~m}^{2}$ plots. This may be due to a lower flow velocity and limited transport capacity in the $1 \mathrm{~m}^{2}$ plot.

Figure 4 - Annual soil loss per unit area at different spatial scales, for the dry tropical forest vegetation cover and splash, burn and cultivation of Andropogon gayanus Kunt

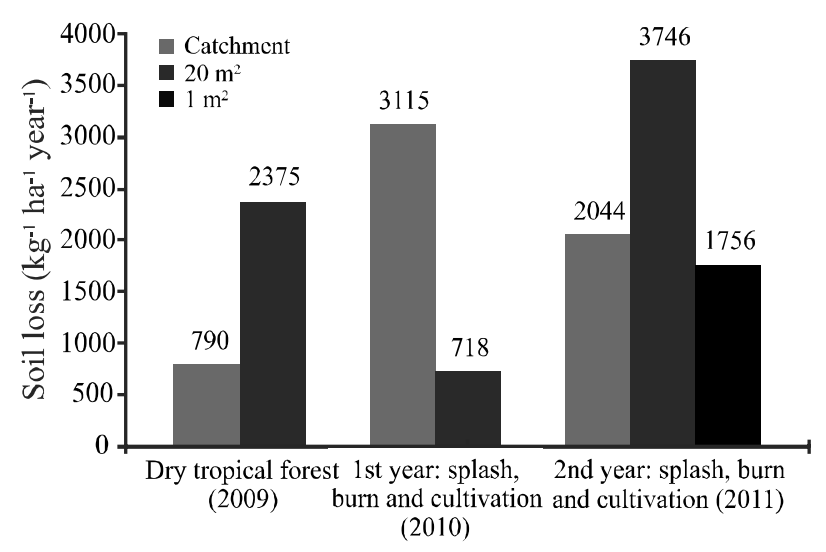

The first year of slash and burn management practice (2010) increased sediment yield by $294 \%$ at the catchment scale compared to the previous period of native dry tropical forest cover, 2009 (Figure 4). This management practice, exposed soil to erosion agents (raindrops and surface flow), favouring soil detachment and sediment transport, rills formation and drainage network redefinition (CERDAN et al., 2010; DLAMINI et al., 2011; GAFUR et al., 2003). Pasture development reduced sediment yield over time, revealing catchment adaptation to the new land cover with development of a more stable drainage system. Nonetheless, the drainage establishment was not observed at the $20 \mathrm{~m}^{2}$ plot scale with a resulting increase in sediment yield relative to the catchment scale.

Land use effect over soil loss is more evident when rainfall is taken into account. Soil loss at the catchment scale is higher in 2010, after the management practice, when compared to 2009 despite the lower erosivity index. Similar behaviour has been reported in other regions after burning (GAFUR et al., 2003; THOMAZ, 2009). Major variations in soil loss relative to runoff at scales ranging from plots to microplots were found in studies developed in southern Italy, where the variation of the mean soil loss during the studied period was ten times larger than the variation of the runoff (BAGARELLO; FERRO, 2004).

On the second year after burning and grass cultivation (2011), soil loss was reduced by $52 \%$ at the catchment scale compared to the previous year, although precipitation and erosivity presented values $72 \%$ and $135 \%$ higher, respectively. The rapid development of the Andropogon gayanus Kunt grass resulted in full ground coverage, reducing soil loss even in a year of high erosivity rainfall events. According to Puigdefábregas (2005), it is widely accepted that runoff and sediment yield decrease with increasing plant cover. This relationship is used in erosion models (MERRITT et al., 2003) to formalise the protective effect of the vegetation.

The high coefficient of determination of the regression equations, especially at the $1 \mathrm{~m}^{2}$ scale $\left(\mathrm{R}^{2}=0.96\right)$, indicates that sediment yield is mainly dependent on runoff and thus, the system is transportlimited, i.e., detached sediments are available to be transferred downstream whenever the surface flow contains sufficient energy. Then, yield occurs at its full potential. Medeiros et al. (2010) reported that in a Brazilian semiarid watershed, sediment yield is limited by transport capacity, due to high erosivity and low runoff depths, resulting in a system with excess sediment and limited transport capacity.

Figure 5 - Runoff versus specific soil loss at the different spatial scales, for the slash and burn and Andropogon gayanus Kunt cultivation in the second year after land use change. Pearson correlation coefficient $(\mathrm{R})$ is significant at the 0.01 level

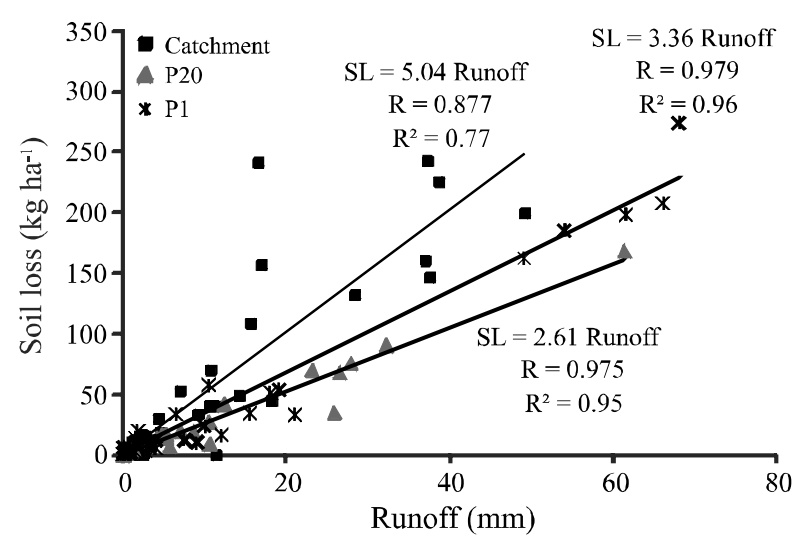


The largest regression slope after slash, burn and grass cultivation occurred at the catchment scale (Figure 5), suggesting that to export the same amount of sediment at the other scales $\left(1 \mathrm{~m}^{2}\right.$ and $\left.20 \mathrm{~m}^{2}\right)$, there is a need for higher runoff values. At the catchment scale, increase in the angular coefficient may be due to detached sediment availability on low magnitude events deposited along its trajectory to the outlet. Because at the catchment scale the runoff coefficient is usually lower, whenever there is surface flow, the available sediment is transported downstream.

Contrary to the hydrological behaviour indicated by runoff data, soil loss data in the first events that generated runoff in 2010 shows the slash and burn strong effect on sedimentological processes (Figure 6). The exposed soil allowed flow energy to increase and transport capacity values were above those necessary to transport the available sediment, causing stream erosion and redefinition of the drainage system (Figure 7).

Figure 6 - Monthly soil loss and runoff at the catchment scale

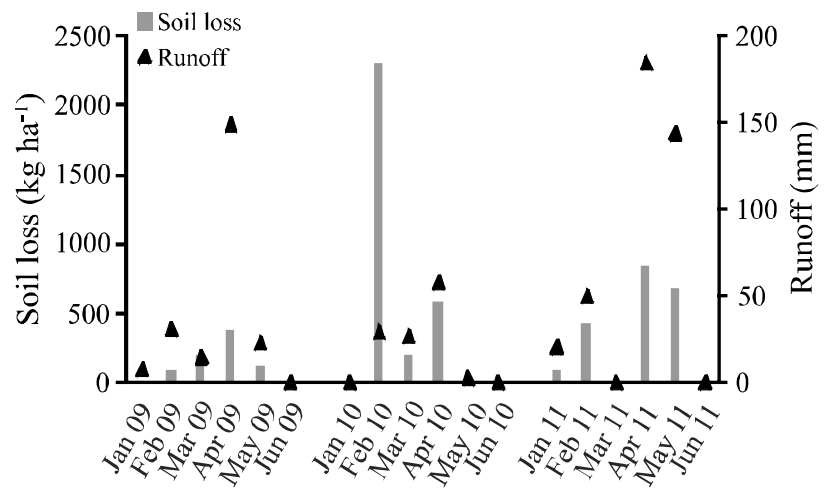

Still in 2010, after grass growth, a decrease in soil loss was observed (Figure 6). The catchment behaved similarly to the native dry tropical forest vegetation cover period after establishment of grass cover in 2011, confirming the importance of vegetation as a major protection agent against erosion (Figure 6). Sediment yield was again controlled by the detachment and flow transport capacity (YAN et al., 2008), in opposition to the on stream processes during the period of adaptation of the catchment to the land use change. As Verheijen et al. (2009) actual soil erosion rates for tilled, arable land in Europe are, on average, 3 to 40 times greater than the upper limit of tolerable soil erosion, accepting substantial spatio-temporal variation.
Figure 7 - Catchment under study in 2010 after management, detail of high sediment production in the course, and in 2011 with the stabilization of the drainage network and development of plant cover
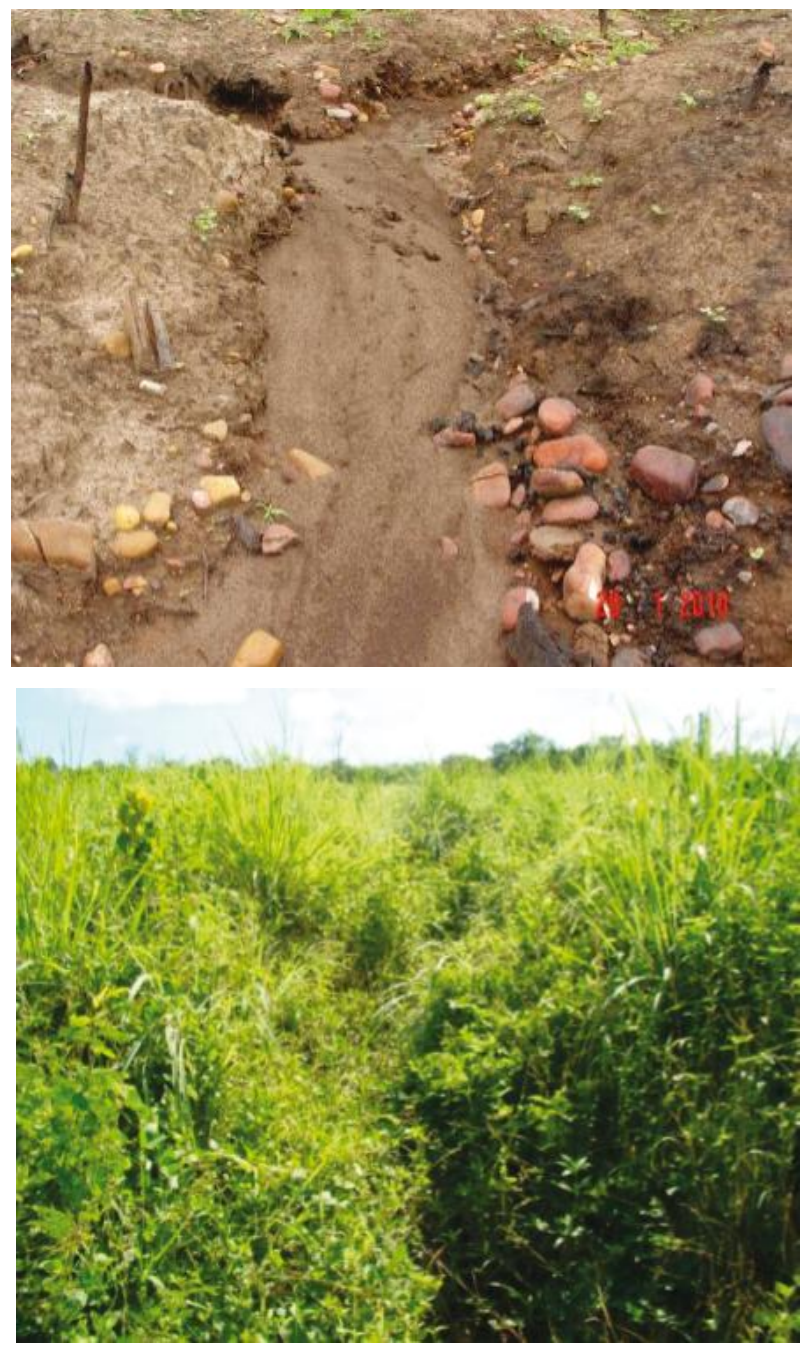

\section{CONCLUSIONS}

1. Slash, burn and pasture (Andropogon gayanus Kunt) cultivation produced an intense change in sediment yield on the studied semiarid area, especially in the first runoff generated events when the catchment was still adapting to the land use change. In the first two events after the land cover change, sediment yield was increased by at least ten times of that observed for similar rainfall evens in the years with native dry tropical forest cover (2009) and after grass full development (2011);

2. The effects of land use change were most noticeable at the catchment scale due to a combination of processes: vegetation suppression increased flow 
energy and enhanced transport capacity, promoting erosion along the stream and redefining the drainage network. Grass development on the catchment stabilized the system and sediment yields regressed to rates observed when land was covered by native dry tropical forest vegetation;

3. Sediment yield is transport-limited at all the scales studied: erosion plots $\left(1 \mathrm{~m}^{2}\right.$ and $\left.20 \mathrm{~m}^{2}\right)$ and catchment ( $2.8 \mathrm{ha}$ ). The measured data indicates the availability of detached sediment to be transported whenever runoff has sufficient energy;

4. No major change on runoff could be observed in the investigated spatial scales after the land use change, suggesting that the vegetation plays a secondary role on the hydrological response of the study area. Indeed, soil is the major feature controlling runoff, particularly on the onset of the rainy season, when macroporosity is high due to the soil shrinkage during the preceding dry period.

\section{REFERENCES}

BAGARELLO, V.; FERRO, V. Plot-scale measurement of soil erosion at the experimental area of Sparacia (southern Italy). Hydrological Processes, v. 18, p. 141-157, 2004.

BAKKER, M. M. et al. Soil erosion as a driver of land-use change. Agriculture, Ecosystems \& Environment, v. 105, p. 467-481, 2005.

BOIX-FAYOS, C. et al. Causes and underlying processes of measurement variability in field erosion plots in Mediterranean conditions. Earth Surf Processes Landforms, v. 32, p. 85-101, 2007.

BOIX-FAYOS, C. et al. Concise review of interrill erosion studies in SE Spain (Alicante and Murcia): erosion rates and progress of the knowledge from the 1980s. Land Degradation and Development, v. 16, p. 517-528, 2005.

CERDAN, O. et al. Rates and spatial variations of soil erosion in Europe: a study based on erosion plot data. Geomorphology, v. 122, p. 167-177, 2010.

CHAPLOT, V. et al. Dynamic modelling for linear erosion initiation and development under climate and land-use changes in northern Laos. Catena, v. 63, p. 318-328, 2005.

CHAPLOT, V.; LE BISSONAIS, Y. Field measurements of interrill erosion under different slopes and plot sizes. Earth Surf Processes Landforms, v. 25, p. 145-153, 2000.

DE VENTE, J.; POESEN, J. Predicting soil erosion and sediment yield at the basin scale: scale issues and semiquantitative models. Earth-Science Reviews, v. 71, p. 95-125, 2005.

DLAMINI, P. et al. Controlling factors of sheet erosion under degraded grasslands in the Sloping lands of KwaZulu-Natal,
South Africa. Agricultural Water Management, v. 98, p. 17111718,2011

FOSTER, G. R. et al. Conversion of the Universal Soil Loss Equation the SI metric units. Journal of Soil and Water Conservation, v. 36, p. 355-359, 1981.

GAFUR, A. et al. Runoff and losses of soil and nutrients from small watersheds under shifting cultivation (Jhum) in the Chittagong Hill Tracts of Bangladesh. Journal of Hydrology, v. 274, p. 30-46, 2003.

GALLART, F. et al. Hydrological processes and their seasonal controls in a small Mediterranean mountain catchment in the Pyrenees. Hydrology and Earth System Sciences, v. 6, n. 3, p. 527-537, 2002.

LE BISSONAIS, Y. et al. Crusting, runoff and sheet erosion on silty loamy soils at various scales and upscaling from $\mathrm{m}^{2}$ to small catchments. Soil and Tillage Research, v. 46, p. 69-80, 1998.

MAYOR, A. G. et al. Scale-dependent variation in runoff and sediment yield in a semiarid Mediterranean catchment. Journal of Hydrology, v. 397, p. 128-135, 2011.

MEDEIROS, P. H. A. et al. Modelling spatio-temporal patterns of sediment yield and connectivity in a semi-arid catchment with the WASA-SED model. Hydrological Sciences Journal, v. 55, p. 636-648, 2010.

MEDEIROS, P. H. A.; ARAÚJO, J. C. de. Temporal variability of rainfall in a semiarid environment in Brazil and its effect on sediment transport processes. Journal of Soils and Sediments, v. 14, p. 1216-1223, 2014.

MERRITT, W. S. et al. A review of erosion and sediment transport models. Environmental Modelling \& Software, v. 18, p. 761-799, 2003.

OAKES, E. G. M. et al. Controls on a scale explicit analysis of sheet erosion. Earth Surf Processes Landforms, v. 37, p. 847-854, 2012.

ORCHARD, C. M. et al. Spatial and temporal variations of overland flow during rainfall events and in relation to catchment conditions. Hydrological Processes, v. 27, p. 23252338, 2013.

PODWOJEWSKI, P. et al. Influence of grass soil cover on water runoff and soil detachment under rainfall simulation in a subhumid South African degraded rangeland. Earth Surf Processes Landforms, v. 36, p. 911-922, 2011.

PUIGDEFÁBREGAS, J. The role of vegetation patterns in structuring runoff and sediment fluxes in drylands. Earth Surf Processes Landforms, v. 30, p. 133-147, 2005.

SADEGHI, S. H. R. et al. Plot sizes dependency of runoff and sediment yield estimates from a small watershed. Catena, v. 102, p. 55-61, 2013.

SANTOS, J. C. N. et al. Runoff and soil and nutrient losses in semiarid uncultivated fields. Revista Ciência Agronômica, v. 42, n. 3, p. 813-820, 2011. 
SCHULER, J.; SATTLER, C. The estimation of agricultural policy effects on soil erosion - an application for the bio-economic model MODAM. Land Use Policy, v. 27, p. 61-69, 2010.

THOMAZ, E. L. The influence of traditional steep land agricultural practices on runoff and soil loss. Agriculture, Ecosystems and Environment, v. 130, p. 23-30, 2009.
VERHEIJEN, F. G .A. et al. Tolerable versus actual soil erosion rates in Europe. Earth-Science Reviews, v. 94, p. 23$38,2009$.

YAN, L. J. et al. Effects of transport capacity and erodibility on rill erosion processes: a model study using the Finite Element method. Geoderma, v. 146, p. 114-120, 2008. 